\title{
EU-ASEAN relations in the 2020s: pragmatic inter-regionalism?
}

\author{
Julie Gilson $^{1}$
}

Published online: 13 June 2020

(C) Springer-Verlag GmbH Germany, part of Springer Nature 2020

\begin{abstract}
The world in the late 1990 s and early 2000 s witnessed a proliferation of region-toregion institutional frameworks. There was a recognition that scale and leverage could create an advantage for economic relations, that security could benefit from crossregion dialogue and initiatives, and that some of the many global challenges, from global climate change to resource depletion, could be addressed more effectively at regional and even inter-regional levels. The EU-ASEAN dialogue itself presents an important model for inter-regional cooperation at the heart of these tangled institutional webs. This article assesses the ways in which the changing multilateral landscape and intra-regional crises within ASEAN and the EU have altered the relevance of interregional dialogue and initiatives.
\end{abstract}

\section{Introduction}

The world in the late 1990s and early 2000s witnessed a proliferation of region-toregion institutional frameworks. There was a recognition that scale and leverage could create an advantage for economic relations, that security could benefit from crossregion dialogue and initiatives, and that some of the many 'new' global challenges from global climate change to resource depletion - could be addressed more effectively at regional and even inter-regional levels (see Hettne et al. 1999). Against this background, the Asia-Europe Meeting (ASEM) was inaugurated in 1996, and the European Union (EU) sought to develop a range of other inter-regional agreements, such as the early Yaoundé agreements and the EU-Mercosur agreement of 1999. Other inter-regional linkages were forged, and included the Association of Southeast Nation States' (ASEAN's) ties with MERCOSUR, with the Cooperation Council for the Arab States of the Gulf (GCC), the South Asian Association for Regional Cooperation (SAARC) and the Rio Group, which became the Community of Latin American and Caribbean States (CELAC). Indeed, the EU and ASEAN sat in the driving seats of all

Julie Gilson

J.A.Gilson@bham.ac.uk

1 University of Birmingham, Birmingham, UK 
of the major inter-regional agenda, with the US continuing to engage trans-regional formats (such as NAFTA) alongside its bilateral alliances.

The EU-ASEAN dialogue itself presents an important model for inter-regional cooperation at the heart of these tangled institutional webs. It began in 1977 when the tenth ASEAN Foreign Ministers' Meeting agreed to intensify the formal elements of ASEAN's relations with a number of key state partners, as well as with the European Economic Community. ${ }^{1}$ There followed in 1980 the signature of the ASEAN-EEC Cooperation Agreement, which institutionalised relations by setting out a long list of economic and development initiatives, and which sought to engage in joint actions 'on the basis of equality, respect and mutual benefit." With the expansion of ASEAN and (by then) EU membership, in 2007 the Nuremberg Declaration on an EU-ASEAN Enhanced Partnership set out a longer term vision for mutual cooperation and dialogue based on shared values, including democracy and human rights. In so doing, this declaration pledged the further development of cooperative actions in fields as diverse as climate change, arms control, money laundering and within various multilateral frameworks, including the United Nations. ${ }^{3}$ Importantly, it also expressed support for the launch of negotiations into an EU-ASEAN free trade agreement (FTA), although in the event this was to be suspended in 2009, in favour of EU agreements with specific ASEAN states.

Interestingly, the 2007 Declaration also pledged cooperation in the attempt to address broader transborder issues, such as the UN's Millennium Development Goals as well as climate change and environmental protection, including the sustainable management of forests. As meaningful progress was slow to emerge, the 2012 ASEAN-EU Ministerial Meeting in Bandar Seri Begawan, Brunei, devised a Plan of Action to implement the cooperation envisaged in the 2007 Declaration, and to cover the period from 2013 to 2017.

The EU's 2015 document, EU and ASEAN: A Partnership with a Strategic Purpose, was written as a precursor to attempts to formulate a Strategic Partnership Agreement between the two sides. ${ }^{4}$ The EU recognised at the time ASEAN's growing intraregional ambitions, particularly the aim of completing the ASEAN Economic Community (AEC) by the end of 2015, which it subsequently achieved. In these endeavours, the EU recognised that they were 'partners in integration,' and sought to boost trade and investment with the region, as well as to foster both intra- and inter-regional connectivity in a range of ways. A blueprint for implementing the AEC was then published within ASEAN, alongside a range of other blueprints for Political-Security and Socio-Cultural Communities. ${ }^{5}$ Moreover, aiming to realise the promise of a 'more rounded partnership,' the EU document clarified ways in which the post-Lisbon Treaty EU, with a greater security remit, could work with the regional initiatives both sponsored and attended by ASEAN in Asia, including the ASEAN Regional Forum

\footnotetext{
${ }^{1} \mathrm{https}$ //asean.org/?static_post=joint-communique-of-the-tenth-asean-ministerial-meeting-singapore-5-8-july1977, accessed on 11 November 2019.

2 https://asean.org/?static_post=external-relations-european-union-asean-eu-ministerial-meetings-asean-eecjoint-declaration-1980, accessed on 11 November 2019.

${ }_{3}^{3}$ https://ec.europa.eu/commission/presscorner/detail/en/PRES_07_54, accessed on 11 November 2019.

${ }^{4} \mathrm{https} / /$ eur-lex.europa.eu/legal-content/EN/TXT/PDF/?uri=JOIN:2015:22:FIN\&from=EN, accessed on 11 November 2019.

${ }^{5}$ https://asean.org/asean-economic-community, accessed on 11 November 2019.
} 
and the East Asia Summit. Subsequently, in 2017 at the ASEAN-EU Post-Ministerial Conference in Manila on the occasion of the fortieth anniversary of the establishment of the EU-ASEAN dialogue, another Plan of Action (covering 2018-2022) was put forward, in order to frame a clearer strategic future for the collaborative activities of the two regions. ${ }^{6}$

This renewed attempt to define the partnership and its 'strategic purpose' underlined the recognition that today the EU and ASEAN remain important trading, political and security interlocutors. In 2016, the total trade between the two regions amounted to US\$229.7 billion, making the EU the second largest trading partner for ASEAN (after China), and making ASEAN the third largest for the EU (after China and the US). Beyond the remit of this article, it is, nevertheless, important to note that the EU remains the largest source of foreign direct investment (FDI) for ASEAN (at 31.5\% of total ASEAN FDI), and that work on a future ASEAN-EU Free Trade Agreement continues, as agreed in their joint statement of March 2017.

Despite these collective steps forward, during the past decade any attempt to enhance the partnership between the EU and ASEAN has been diluted by a growing trend for the EU to deal bilaterally with the individual states of ASEAN, rather to engage in inter-regional dialogue (Boisseau du Rocher 2012; Fitriani 2014). In fact, the EU completed FTAs with Singapore and Vietnam in 2019, and is in negotiations over FTAs with Thailand, Malaysia, the Philippines and Indonesia. Such a preference for bilateral agreements has been motivated by the failure to achieve a free trade agreement between the two regions, as well as by the more fundamental differences in economic structures and levels of development within the states involved, as well as in their varied levels of adherence to democratic principles, including the protection of human rights. In 2020, one further complication in attempts to forge greater inter-regional agreement has been the departure of the United Kingdom from the European Union as a result of the 'Brexit' process. The UK's exit has removed from this trading bloc one of its most significant economic, political and security members, accounting for approximately $16 \%$ of the EU's gross domestic product. The implications of this loss will be explored below.

The first section of this article sets out how inter-regionalism came to be framed in academic debates and the challenges the scholarship now faces. This is followed by a section assessing the ways in which the changing multilateral landscape and intraregional crises within ASEAN and the EU have altered the relevance of inter-regional dialogue and initiatives. And section three examines the prospects for 'pragmatic interregionalism' in the face of new global and regional challenges, including Brexit.

\section{Framing region-to-region dialogue}

The origins, relevance and agency of regions have been studied since the establishment of the European Coal and Steel Community in the 1950s, as models of economic activity, political and administrative expediency, shared socio-cultural behaviours, and as defensive political or security mechanisms in the face of external threats or challenges (see, for example, Gilson 2002, Hutt 2019: 2-11; and Hettne et al. 1999: xxi). Regarded

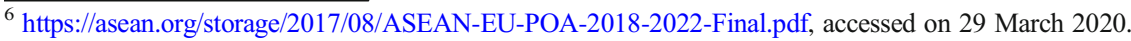


variously as institutions (Keohane et al. 1993), social processes (Hettne et al. 1999: xv) and normative projects (Acharya 2004), growing debates in the 1990s and 2000s around the relative 'actorness' of regions also drew greater attention to their interaction with similar others. These processes took root and in many cases grew out of 'double regional projects,' bringing pre-constituted and formally recognised regional bodies together (Gilson 2002). In other cases, a less formal, or even notional form of inter-regionalism could be seen to develop as a result of a process of regional emulation, whereby new regional arrangements came to be constructed in order to deal with the challenges posed by the processes of globalisation. This latter process, saw, through mimétisme, the potential for growing 'counterpart coherence' over time and in many cases the EU was seen to provide the definitive manual for regional behaviour (Aggarwal and Fogarty 2004: 19). This growing web of region-to-region dialogues further stimulated interest in the idea of inter-regionalism itself.

Interest throughout the 1990s and 2000s in inter-regionalism grew out of a growth in regional level organisations and initiatives from the 1950s, and the debates their existence elicited (see, for example, Rosamond 2001). What soon became clear, was that there did not exist one model for region-to-region cooperation, and scholars framed the concept of inter-regionalism around the motivations for engagement and the mode of engagement itself. First, the reasons for which regions might choose to work with one another and, indeed, for states to coalesce around a regional framework, will delimit the scope and remit of that interaction. Thus, inter-regionalism may represent the organic and/or ad hoc growth of specific sectoral agreements; it may derive from a desire to pool general or particular resources or to recognise mutual interests; or it might offer a defensive set of structures in response to global trends and challenges (Gilson 2002: 3-11). Second, the mode of interaction may bring together formally recognised, institutionally constructed regional entities in an explicitly inter-regional arrangement, or it may be formed by a more implicit inter-regionalism in which loose coalitions of states come together as 'notional' regions. The latter might include arrangements such as the Asia-Europe Meeting (ASEM) or the Asia Pacific Economic Cooperation (APEC) dialogue.

During the 2000s, reflections on regionalism per se issued from concerns about the reshaped world order in the wake of the ending of the Cold War, and in response to the transformative forces of economic globalisation (Gilson 2005; Hurrell 2007; WarleighLack et al. 2011). Indeed, 'new regionalism' focused specifically on the international economic context of the post-Cold War era, and broke down the stratification of layers of governance, to produce instead a reading of regions within a more complex layering of authority (Väyrynen 2003: 44; see also Hettne and Söderbaum 2000).

Against this background, inter-regionalism came to be regarded by some observers as a site for normative transformation, notably as the varied forces associated with globalisation enhanced the need for economies of scale, and as the project of European integration became increasingly influential as a foreign policy actor. In the case of ASEM, for example, there was a clear push for an 'Asian' regional side to form itself in order to become a meaningful interlocutor for the Europeans (Gilson 2005). Thus, regions came to be described not only in structural and economic terms, but also as ideational categories demonstrating a particular kind of actorness, as illustrated in the special edition of the Journal of European Integration in 2005, edited by Söderbaum and Langenhove (2005: 258). 
Both the practice and the concept of inter-regionalism have been challenged by events of the 2000s and 2010s, which will be explored below, and which include the rise of bilateral free trade agreements (FTAs) and state-led challenges to the prevailing architecture of international relations, such as from the rise of the so-called 'BRICS' (Brazil, Russia, India, China and South Africa) grouping. These new global conditions have resulted in a decline in interest in inter-regionalism during the past decade, but they also speak to a need to understand regional and collective behaviours in a different way. The following section follows the lead of Jürgen Rüland, to draw a more diffuse concept of 'pragmatic inter-regionalism' and to apply it to contemporary EU-ASEAN relations (Rüland 2007).

\section{Pragmatic inter-regionalism}

The idea of pragmatic inter-regionalism, which takes its inspiration and key concepts from Rüland's work, is characterised in this present article as resting on the four principles of: nesting; fluidity and flexibility; core drivers; and power balancing.

\subsection{Nesting}

First, the idea of nested inter-regionalism is based on the work of Aggarwal, and ensures that new forms of network conform to prevailing structures and norms and may occupy a particular position within the architectural hierarchy (Aggarwal 1998). For Aggarwal, this nesting process involves groups of actors collected at a specific level of interaction to draw upon 'elements from the framework of broader institutions to make them compatible while providing an element of hierarchical goal ordering' (Aggarwal 1998: 1). In the case of region-to-region engagement, this model locates particular relationships as existing within a greater (and lesser) set of structures and discourses, thereby affecting the substance of inter-regionalism itself.

Importantly, this approach enables the researcher to study the role of interregionalism within an increasingly fragmented, decentralised and multi-layered global context (Scholte 2000: 143). This approach echoes Rüland's call for understanding how institutions play multiple roles, including 'hedging,' in order to manage the need to balance different sites of power and to respond to different levels of institutionalisation (2011: 106). In these ways, inter-regionalism has the potential to respond to concerns that state and sub-state levels are being transcended, while global arrangements have yet to be effectively formatted, and facilitates analyses of the constraints imposed by the global political economy, as well as by new transborder challenges, notably climate change (see, for example, Breslin et al. 2002). Finally in this context, by regarding inter-regionalism as a nesting process, the tendency for 'forum shopping' can be explained, as actors 'pick and choose among the mechanisms that best fit their individual political agenda' (cited in Rüland 2012: 256).

Inter-regionalism for the EU and ASEAN, in this way, comes to be regarded as one site of engagement and problem-solving among many others. At the same time, the normative substance of inter-regionalism itself continues to be seen to hold the potential to influence the constituent actors involved, in line with earlier approaches to interregionalism. In this way, whilst the structure may facilitate a reduction in transaction 
costs and may engender particular patterns of interaction (Keohane et al. 1993: 175), it may also shape 'the social script through which institutional participants communicate' (Wendt and Duvall 1989: 60). In this formulation, the 'region' becomes a reflexive agent that both constitutes and is constituted by, its inter-regional interaction and its 'ongoing externalization' (Scholte 1996: 69-70). In so doing, it may contribute to the very idea of the region per se as a political actor (Gilson 2005). In addition to providing practical solutions to managing international relations, therefore, inter-regionalism may even intensify difference in the face of a definable 'other' and develop a foundation of common norms (see Rüland 2010).

\subsection{Fluidity and flexibility}

Second, the concept of flexibility refers to a practical need for institutional arrangements to accommodate an inclusive membership and remit, in order to be defined as 'regions' or 'inter-regionalism.' However, the de facto proliferation of new regional organisations, sub-state groupings and other international bodies, for shorter and longer term ambitions, illustrates how the line between formal and informal regionalism has become blurred in recent years. A case in point is the ASEM group, which previously heralded the coming-together of two regions ('Asia' and 'Europe') but whose membership has now become increasingly blurred, as states such as Australia and Russia belong to both and neither region simultaneously. Thus, flexibility of membership begins to be regarded as an important advantage, to enable regional and inter-regional bodies to address a range of complex agenda in a variety of ways.

Flexibility of membership is complemented by a need for fluidity in terms of agenda and remit. The past decade has demonstrated within the EU - particularly in terms of its approach to China - a flip-flopping of approach that has both tightened and loosened core criteria in order to strengthen relations. However, what has become apparent more recently, is the need to show flexibility in terms of engaging in a range of dialogues to respond to contemporary challenges, whilst retaining a set of core drivers upon which the relationship continues to be based.

\subsection{Core drivers}

As shown below, not least in terms of defining contemporary security requirements, the EU-ASEAN dialogue forces a re-examination of its original core values. What is clear is that the core drivers need to work for both sides of the institution, and it may be that, in the case of EU-ASEAN, there is a need to move away from fundamental attachment to specific principles and values, such as human rights. However, without some form of value anchoring, the case for an institutionally framed set of relations becomes untenable. This approach, then, continues to recognise that the functional and cognitive value of institutional definition continues to be important, as Söderbaum and Van Langenhove noted (2005).

\subsection{Power balancing}

Finally, the need to address the role of power balancing within inter-regionalism has become more prominent. Throughout the 2000s, scholars like Hamanaka observed how 
the behaviour of regions continued to represent a 'struggle for leadership' (2011: 257), whilst Rüland recognised the need to address power disequilibria (2011: 89). In particular, Rüland draws our attention to the ways in which inter-regional forums can create protective mechanisms, which seek to 'impede, dilute and delay hegemonic policies,' and which serve to protect member states against new and unchartered challenges and to promote development strategies (2011: 90).

In so doing, inter-regionalism offers an important framework for performing 'soft balancing,' which involves inter-regional forums in short-term coalition-building (Rüland 2010: 1274), designed to alleviate some of the pressures by creating high levels of economic interdependence (He 2008: 489). Such power balancing may also refer to both strategic-security and also economic interests, and supports the collective management of external realities (Gilson 2005). The following section will highlight some of the principal changes faced by the EU and ASEAN, before examining the inter-regional agenda per se, through an analysis of these four elements.

\section{A changing multilateral landscape}

The inter-regional pledges and initiatives between the EU and ASEAN set out above were made against a background of a rapidly changing global order and in the face of significant regional crises and challenges in both Europe and Asia. Since the global recession from 2008, and with the continuing rise of China, intra-regional difficulties within the European Union and more recent changes in US foreign policy, there have been many challenges to the potential role for inter-regionalism. Arguably, region-toregion engagements like ASEM and the EU-ASEAN dialogue were established and consolidated during a period that witnessed some enthusiasm for regional projects and the politics of scale, and more recent years have seen a marked decline in political interest in these inter-regional engagements, against the backdrop of growing transnational and bilateral free trade agreements in particular.

First, new forms of alliance and engagement have replaced a growing trend for regional and inter-regional partnerships, and include the growth of the BRICS and a growing interest in an 'Indo-Pacific' order following the revival of the Quadrilateral Security Dialogue in 2017. Whilst the BRICS states do not all share the same levels of economic development or regime types, collectively they express 'resentment' at the traditional institutions of global order, including the World Bank (Khanna 2014: 47). Moreover, although Chin warns that the 'heady camaraderie' of the BRICS should not be overstated, the creation of the BRICS New Development Bank in 2013 set out a collective ambition to focus on infrastructure investment, as a direct critique of the G20 process (Chin 2014: 367). Similarly, the creation of China's Asian Infrastructure Investment Bank (AIIB) has raised important questions as to possible pathways to alternative forms of capitalism and about China's capacity to develop a new form of 'leadership with Chinese characteristics' (Beeson and Xu 2019: 354). For its part, the security-focused Quadrilateral sees member states 'vying for influence in the Indo-Pacific' and is at least partially aimed at containing China's security ambitions and bringing Indian interests into the fold, all of which have major implications for the neighbouring states of ASEAN (Wagle 2018). 
Second, the world is a different place. In terms of economy, the impact of the global recession from 2008, and the continuing rise of China, combined with the US withdrawal from the Trans-Pacific Partnership (TPP) in 2017 and the rampant proliferation of bilateral FTAs, including that between the EU and Japan signed in 2018, have all led to a fracturing of some of the basic foundations upon which multilateralism and interregionalism had previously been based. Of particular note, the 2016 TPP, covering 12 countries from the Americas to the Pacific region, sought to remove all tariffs on products, and to liberalise other sectors, including services and investment. Initially resisted by the states of the EU as an institution incompatible with European trading regulation and behaviour, it was regarded by states in Asia as a vehicle for US-led regionalism. Following the withdrawal of the US with the arrival of the Trump administration, the Japanese government assumed a de facto mantle of leadership of this forum, leading to the creation of the Comprehensive and Progressive Agreement for Trans-Pacific Partnership (CPTPP) in 2018, and thereby incorporating most of the original provisions (Gilson 2020). For the states of ASEAN, this new arrangement, though a much reduced geographical scope, remains an important opportunity for economic growth and the creation of further FTAs with and within the region (Rastogi 2018).

The proliferation of FTAs during the 2000s and 2010s can be seen in response to the failure of the WTO's Doha Development Round of trade talks, and from peer pressure to create bilateral agreements once the US and Europe had begun to embrace them (see Meissner 2016). As a latecomer to these agreements, the states of ASEAN quickly pushed ahead to make a concerted imprint on the FTA map.

Kawai and Wignaraja note how ASEAN has adopted them for three strategic reasons: to enhance production networks in light of an expansion in the use of FTAs by the larger states of the region; to foster trade and the liberalisation of investment in a way that the WTO is failing to do; and to embrace the greater flexibility and scope offered by these 'new age' agreements (2010: 2). As a consequence, Protopsaltis witnessed the creation of 'networks of asymmetric preferential trade agreements' (2017: 4), with the potential to undermine the fabric of the multilateral trading order. This sentiment echoes the idea of 'diminished multilateralism' expressed by Rüland, as the new, bespoke arranges come to contest 'the norms, rules and decision-making procedures of international institutions' (2010: 1278). Indeed, some scholars noted that a new era of 'competitive interdependence' had begun, in which FTAs could be used strategically to correct those dis-benefits incurred by the WTO system (Sbragia 2010: 371).

In security terms, among other issues, problems associated with the rise of China and disputes with both Hong Kong and Taiwan, North Korean nuclear ambitions, a changing European and Asian military posture by the US under President Trump, and enduring tensions in Middle East politics, continue to occupy traditional security discourses. In addition, the global threat from climate change, the need to remove fossil fuels, unusually widespread and violent fires California in 2019 and in Australia in 2019-2020, aligned with the failure of the COP25 to garner meaningful responses to these events and the climate emergency, speak to the need also to address more urgently and coherently those new security threats which by their very nature require collective action responses. The Covid-19 pandemic of 2019-2020 brings that urgency into still greater relief and to the heart of daily lives of citizens around the world. As of March 2020, the pandemic had elicited predominantly national responses, underpinned 
by international scientific knowledge housed in particular in the World Health Organisation. Regional and inter-regional responses may, however, be called upon for longer term resolution and for future planning.

\section{Intra-regional challenges}

The regions of Europe and Southeast Asia have themselves altered over the past decade, and it is worth noting briefly some of the principal changes faced by each regional grouping.

\subsection{ASEAN in transition}

During the 1990s and 2000s, the states of East Asia appeared to embrace a new idea of regionalism, setting out an apparently coherent path towards a more unified economic and political region, and beginning to identify themselves with an East Asian community (Gilson 2005). ASEAN has developed a wide range of institutional structures for addressing a variety of mutual concerns, including issue-specific fora like the ASEAN Inter-Parliamentary Assembly and ASEAN Business Forum, and broader arrangements like the ASEAN Regional Forum (ARF), established in 1994 as a confidence-building measure to foster preventive diplomacy in matters of politics and security. Recent years have been spent developing a Human Rights Mechanism and working towards the December 2015 deadline for the completion of its intra-mural economic community. From its inception, embedded in the fabric of its make-up was the 'ASEAN Way;' a modus operandi based on a set of principles including non-interference and consensusbased decision making housed within only a loose structural form (Haacke 2005). These principles, although frequently challenged and debated by scholars and practitioners alike, continue to be reflected in discussions about East Asia as a region today, at the heart of which has been ASEAN (Nesadurai 2008).

However, in trying to respond to great power rivalry and the development of the Indo-Pacific initiatives in particular (see below), ASEAN has in fact offered no distinctive leadership and the central position of Indonesia within it has also declined. Parameswaran adds to this factor the changing internal dynamics of ASEAN, particularly with the rise of Vietnam, and the juxtaposition of democratic and non-democratic governmental regimes, to show inconsistency and incoherence within this regional bloc (2020). As a result, discussions over the centrality and relevance of ASEAN for regional cohesion and inter-regional engagement have continued (see, for example, Stubbs 2019).

\subsection{The EU in turmoil}

The 2010s have witnessed some of the most tumultuous years in the history of the EU (see Gilson 2020). Following the 2008 economic crisis, it faced a sovereign debt crisis in Greece and severe economic instability in other states, including Ireland, Portugal, Spain and Cyprus, all of which fractured the possibility of a common approach and resolution. This fracturing could also be seen in responses to the severe migrant crisis of the 2010s, with Italy and Greece left to bear the brunt of the problem on their shores. 
Added to these problems, the inauguration of President Trump heralded the start of a period of relative tension, as Trump declared the EU to be a 'trade foe' and in 2017 scrapped the Transatlantic Trade and Investment Partnership (TTIP) and withdrew from the Paris Agreement on climate change.

These problems were compounded by the protracted and difficult negotiations between the EU and the UK, following the UK's 2016 referendum decision to leave the EU, with a vote of $51.9 \%$ in favour of 'Brexit' and $49.1 \%$ against (Gilson 2020). During that period, Japan and the EU were in the midst of negotiating their Economic Partnership Agreement (EPA), and the Japanese government issued unprecedented warnings to the UK about the likely implications of Brexit for Japan-UK trade. Faced with a possible 'no-deal' Brexit, whereby the UK reverts to WTO rules, the Japanese Ambassador to the UK even stated: 'I don't think the single market could be substituted by something and be better or even be the same' (Helm 2018). During subsequent months of UK-EU discussions in 2018 and 2019, the Japanese prime minister pressed the UK to secure a deal with the EU, and not to risk a no-deal exit (Elgot and Sabbagh 2019). In particular, concerns were expressed about the long-term commitment to the UK of Japanese companies like Nissan and Honda, were they to lose the advantages of frictionless trade within the perimeter of the EU. Numerous commentators emphasised the UK's comparative advantage as a 'gateway' to the EU market (Suzuki 2017: 861; Tsuruoka 2016), a position French President Emmanuel Macron has been keen to take over (Gilson 2020).

All of these problems illustrate how the attention of this regional grouping has remained far from most of Asia during the past decade, with the exception of the major Economic Partnership Agreement and Strategic Partnership Agreement with Japan, signed in 2018 (see Gilson 2020). Thus, with intra-regional difficulties within ASEAN and the EU and more recent changes in US foreign policy, there have been many challenges to the efficacy of inter-regionalism.

\section{Developing pragmatic inter-regionalism?}

Given the changes to the global environment in which they interact, to what extent are we witnessing a preference for pragmatic inter-regionalism between the EU and ASEAN today?

\subsection{Nesting}

First, the EU-ASEAN relationship remains anchored within the structures of global governance in a number of ways, and, notably, the remit and scope of the dialogue is based on, and responds to, the normative and substantive content of the WTO and the United Nations. However, the authority, scope and impact of a number of international institutions has been called into question: the WTO's Doha Development Round has failed to deliver on its agenda; the UN's climate conferences have not resulted in substantive and meaningful global agreement; and regional institutions have been challenged by political intervention and competition. For example, efforts in the 1990s and 2000s, including by China, to embrace multilateral dialogue, not only through the ASEAN Plus Three process, but also in its global reach, notably within 
the WTO, seemed to herald a common desire among key states for trilateral management through institution building and the initiation of discussions about a collective vision for the region appeared to mask or manage its ongoing bilateral tensions (see Roy 2005), as China appeared to embrace a more cooperative policy of 'peacefully contested change' (Deng and Moore 2004: 134).

In the event, however, these ambitions have been superseded by a divergence of views: China has articulated its opposition to Japanese policy over a range of issue, most prominently the Senkaku/Diaoyutai dispute, and has expressed this disagreement in a form of institutional opposition in East Asia itself, by supporting the ASEAN Plus Three process in preference to the East Asia Summit preferred by Japan. The geographical expansion of the EAS, to include the US and Russia, further reduced the original East Asia vision, and by 2013 topics were loose and broad and the Chair's Statement, to the extent that it mentioned the 'region,' reinforced 'ASEAN's centrality in the regional architecture,' but did not engage with rhetoric about the region's ambitions. ${ }^{7}$ Simultaneously, the withdrawal of the US from the region, especially from the TPP, has elicited concerns of a reduced US commitment there overall, as illustrated below (see Auslin 2012).

In the case of the US, following an apparent (if somewhat vague) attempt by the US Obama administration to 'pivot' towards East Asia (Shambaugh 2013: 12; see also Gilson 2020), President Trump's vacillations towards the region have presented both threats and opportunities for the EU-ASEAN dialogue. Thus, whilst the changing vagaries of great power politics become increasingly challenging for the EU and ASEAN, the relative absence of the US from East Asia could offer the EU an opportunity to position itself as a regional partner and potential broker alongside ASEAN. In these ways, contemporary 'nesting' rests less on allegiance to normative frameworks originating from a democratic liberal order, and more from a need to balance power politics. This will be developed further below.

For its part, intra-regional issues within the EU and especially the complicated departure of the UK from the Union, have contributed to a weakened European focus on East and Southeast Asia, for three broad reasons. First, negotiations between the UK and EU are underway to secure an agreement to take forward their new relationship at the end of the transition period on 31 December 2020 (Edgington 2020). In the early months of 2020, a range of challenging issues had already been identified, and include the potential role of the European Court of Justice, fishing rights, and environmental and labour rights, alongside the nature of the final partnership agreement itself. And whilst some commentators remain optimistic that a general alignment of interests can be achieved, ${ }^{8}$ others note that the possibility of no-deal remains on the table (O'Carroll 2020). Under those circumstances, adhering to WTO rules, the UK would see tariffs applied to most of the goods it exports to the EU, and the imposition of border checks, making those goods more expensive to buy. Other potential implications would be the loss of mutual recognition of qualifications and more complex procedures for work travel. As of March 2020, trade deals had been agreed by the UK with states amounting to approximately $8 \%$ of its total trade (Edgington 2020). The UK continues to push for

\footnotetext{
${ }^{7}$ www.mofa.go.jp/mo sfaj/files/000016962.pdf, accessed on 29 March 2020.

${ }^{8}$ https://www.cer.eu/insights/future-eu-uk-relationship-and-relative-case-optimism, accessed on 29 March 2020.
} 
a variation on the agreement between Canada and the EU, but the reality is that the Canadian market is much smaller and narrower in terms of EU trade.

The second reason for which there may be a further weakening in European attention towards Asia due to European internal concerns pertains to the focus of both the UK and the EU on the role and economic interests of the US. In February 2020, newly installed European Commission President, Ursula von der Leyen and US President Trump jointly stated the intention to advance negotiations towards a bilateral EU-US trade deal. The European Commission is keen to remedy the negative effects of US tariffs imposed in October 2019, following a WTO case over aircraft subsidies, which were deemed to be illegal; and to deal with an American president who finds Europeans 'more difficult to do business with than China' (Politi et al. 2020). For the UK under the leadership of Prime Minister Boris Johnson, there is a pressing need to secure a trade deal with the UK's single biggest export and import market.

Finally, in the early stages of the Covid-19 virus in Europe (as of the end of March 2020), there have been no significant EU-wide responses and little cooperation between the UK government and its European regional counterparts. The likely severe economic implications of the Covid-19 outbreak throughout Asia and Europe in 2020 may further complicate those negotiations between the UK and the EU. An urgent virtual summit of EU leaders in March 2020 failed to secure a common financial response, and no common measures to close borders or restrict the movement of persons were agreed. ${ }^{9}$ In this initial phase, the fracturing seen in the light of the financial crisis and migrant crisis continues to be in evidence.

\subsection{Flexibility and fluidity}

Today, excluding ASEAN, most of the institutions of East Asia are broad in their membership and remit, echoing agendas set elsewhere (notably in the UN and WTO) and indicating little about the role of the region per se in securing the future. At the core of the need for greater flexibility, is a rapidly changing agenda of international issues, emanating both from traditional security concerns as well as non-traditional security issues (Maier-Knapp 2016).

In fact, today, under the latest Action Plan, the EU-ASEAN dialogue covers a large gamut of subject matter, and in addition to the pursuit of a region-to-region FTA, they are seeking to adopt an air transport agreement. In other sectors, they are pursuing joint disaster management and response initiatives, and educational programmes. The EU since 2012 has been party to ASEAN's Treaty on Amity and Cooperation, designed to enhance stability and security in the region. In so doing, both sides seek to upgrade the relationship into a Strategic Partnership. Responding to the key issue of our time, moreover, the first ASEAN-EU high level dialogue on sustainable development took place in November 2017, and aims to promote the implementation of the Paris Agreement on Climate Change. The 2019 meeting pledged to work towards 'designing enabling conditions at regional scale. ${ }^{10}$ Beyond a need to fill a regional gap, then, there

\footnotetext{
${ }^{9}$ https://www.euronews.com/2020/03/27/covid-19-eu-leaders-fail-to-agree-on-common-financial-responseduring-virtual-summit, accessed on 29 March 2020.

${ }^{10} \mathrm{https}$ //asean.org/storage/2019/09/Overview-of-ASEAN-EU-Relations-as-of-August-2019.pdf, accessed on 29 March 2020.
} 
is a need to respond actively to multi-layered problems and challenges, and Peyrouse reminds us to look beyond headlines of EU-ASEAN encounters, to see a growing desire to set up meetings about issues of mutual interest - such as connectivity - and to enhance the visibility of the EU in the region (2012).

Thus, these existing structures, however loose, remain important for EU-ASEAN relations, even where key agreements are not yet secured. At the same time, formal institutional progress continues to have meaning, as the 2012 EU accession to the Treaty of Amity and Cooperation in Southeast Asia (TAC) shows. Essentially, the EU recognises a need to gain and retain a 'foot in the region' (Meissner 2016: 333), through both bilateral and inter-regional, structured and ongoing, and ad hoc, means. To this end, the recent discussions about revivifying the FTA between the EU and ASEAN are noteworthy. On the one hand, the 2019 bilateral FTAs between the EU and Singapore and with Vietnam, respectively, have been regarded - particularly in light of the completion of the ASEAN Economic Community - as 'building blocks' for a broader agreement, and cover $45 \%$ of the EU's trade with ASEAN. ${ }^{11}$ On the other, although the bilateral agreements have also put other ASEAN states under pressure to develop their own FTAs with the EU, these two agreements already give the EU an important foothold into the key telecommunications, financial and information technology industries within the region. To date, neither strategy has borne fruit. What seems to be clear is that these and other discussions highlight, as Rüland observed, an inadequacy in the academic literature on inter-regionalism, and underline a need to understand the impact of the rise of 'contingent broadband multi-purpose institutions' (2010: 1280).

\subsection{Core drivers}

During the 1990s, there was a significant body of scholarship devoted to understanding the normative reach of the European project, rooted in Western liberal capitalism and founded on a fundamental set of principles around individual human rights. In recent years, however, and not least in the light of the myriad internal challenges faced by the EU in having to (re)define its own identity, this project has waned. Whilst the EU has retained a focus on normatively driven cooperation with, for example, the respect for human rights as a fundamental basis for agreement with other states, the states of East Asia historically have preferred to work on the basis of consensual dialogue. This distinction has been at the heart of problems in bringing together Europe and Asia in the past, as Asian values have often been portrayed as being in tension with the ways of doing business in Europe (see, for example, Emmerson 1995).

Against this background, does the EU-ASEAN relationship today rest on core drivers of shared interest and commitment? Most significantly, in light of recent events, and against the background of an increased need for flexible responses to multiple challenges, the EU-ASEAN dialogue may continue to evoke shared values, but in reality needs to find agile and practical responses. This apparent fracturing of normative frames is located within a broader discussion about the erosion of a dominant international neoliberal logic, not least as a result of the proliferation of FTAs around the world, which might be regarded as dismantling

\footnotetext{
${ }^{11} \mathrm{https}: / /$ ec.europa.eu/trade/policy/countries-and-regions/regions/asean/index_en.htm; https://www.bilaterals. org/?is-there-an-eu-asean-trade-deal-on, accessed on 19 November 2019.
} 
the logic of regionalism with the attendant rise of bilateralism, by utilising such preferential agreements as strategic national foreign policy tools (see Capling 2008).

In addition, there has been a rise not only in the impact of alternative forms of capitalism, but also in the power and influence of non-democratic states, which do not require many of the conditionalities (such as adherence to human rights' commitments) previously underpinning institutional agreements. Thus, for example, as China sets out the agenda for its New Silk Road, negotiations for an EU-ASEAN FTA, relaunched in 2017, are likely to be made difficult by concerns over palm oil production in Malaysia and Indonesia, and over the human rights' records of Cambodia and Myanmar, as well as the regime of Duterte in the Philippines. ${ }^{12}$

In these ways, the EU faces the difficult challenge of needing to retain its commitment to fundamental norms, whilst cherry picking its way through bilateral agreements in the region (Yeo 2018). This crossover may signal the move towards a more pragmatic engagement over issues of mutual interest and could yield greater cooperation, and a move away from the European 'desire to export its own version of regional actorness' (Mattheis and Wunderlich 2017: 731). In the same vein, the expressions of regionalism within ASEAN of the 1990s and 2000s and the unqualified 'idea' of the region saw a movement - in parallel to the developments that had unfolded in Europe over many decades towards mutually institutionalised arrangements for the management of collective action goals, most notably through the creation of the ASEAN Plus Three process and the reinforcement of the centrality of ASEAN norms, or so-called Asian values.

However, this region faces a dilution of any regional identity that may have been emerging, and a greater incentive for ASEAN states to align themselves with Chinese projects led by its New Silk Road and financed by the AIIB. Thus, where, for example, in 2005, the Japan-ASEAN Summit 'acknowledged that the East Asian community is a long-term goal that would contribute to the maintenance of peace, security, prosperity and progress in the region and beyond, ${ }^{, 13}$ this initiative has not progressed, and instead China has championed alternative structures and agendas (Goh 2011: 895). In these ways, it appears that we are witnessing an erosion of some of the core values on which the original EU-ASEAN dialogue was premised.

\subsection{Power balancing}

One of the principal developments in recent years has been in the changing geopolitical contours of Asia, particularly in changes driven by the role of the US and that of China. First, the Trump administration has caused a 'disruption' to EU-ASEAN (and beyond, for example in relation to the TTIP), by undermining the global trading regime, ${ }^{14}$

\footnotetext{
12 https://www.bilaterals.org/?is-there-an-eu-asean-trade-deal-on, accessed on 19 November 2019.

$13 \mathrm{http} / / /$ www.mofa.go.jp/region/asia-paci/asean/conference/joint0512.html, accessed on 19 November 2019.

$14 \mathrm{https}$ ///books.google.co.uk/books?hl=en\&lr=\&id=sdBwDwAAQBAJ\&oi=fnd\&pg=PA109\&dq=euasean+and+trump\&ots $=$ fcjODtm-KL\&sig=2MrN0ItoZJTVlmDUa3YMOoIuZkU\&redir_esc $=\mathrm{y} \# \mathrm{v}=$ onepage \&q=eu-asean\%20and\%20trump\&f=false, accessed on 19 November 2019.
} 
through an ongoing 'assault on free trade norms and disdain for global institutions and multilateral initiatives. ${ }^{15}$ Moreover, in a post-pivot US, interest in Asia suggests both withdrawal from the region and a set of critiques of its members, which all signal to regional states a waning US commitment to regional security. Even in the face of a number of recent initiatives, scepticism towards the US' apparent intentions in the region remains strong. ${ }^{16}$ The US has been unwilling to intervene in attempts to resolve growing tensions between Japan and South Korea, whilst its 'increasingly protectionist treatment of traditional allies, exclusionary policies toward strategic competitors, and noncommittal attitude to global challenges like climate change, are muddying international views regarding its commitment to inclusive prosperity. ${ }^{, 17}$ As an important aside, one of the ways in which the US has sought to articulate its Asian regional role has been in the renewed Indo-Pacific framework. ${ }^{18}$ As yet, participating member states have still to articulate a common vision of a future Indo-Pacific agreement or arrangement. $^{19}$

Second, the Chinese government has been working hard both to court and to threaten the Southeast Asian states. The ASEAN-China Free Trade Agreement of 2002 paved the way for a 2010 ASEAN-China Free Trade Area (Stubbs 2014: 535), thereby cementing Chinese ties to Southeast Asia, and placing ASEAN in a position firmly wedged between these two regional powers. The inauguration of the AIIB in 2014 in particular has been regarded as a means of 'wooing' Asian states into China' own regional ambit, 'offering the carrot of development as a means to serve its geopolitical ends' (Lam 2014: 127). It has also offered military equipment to Thailand and counter-terrorism support to the Philippines. ${ }^{20}$ Whilst Acharya urges caution against assuming that such actions demonstrate an interest to 'supplant the existing order' (2015: 5), these new initiatives nevertheless weaken coordinated attempts to develop a regional framework for cooperation.

Simultaneously, China continues its acts of provocation in the South China Sea, which causes the states of ASEAN to be on alert not only to China, but to the US' 'sabre-rattling' in response to Beijing's actions. In this area, observers see the likely development of a new status quo which includes a strong Chinese military presence in these waters, particularly as China seeks to restrict regional states from engaging in military exercises with other states. ${ }^{21}$ In the face of these external politico-security and economic pressures, there may also open up opportunities for closer collaboration with European allies, as part of what might become a 'thickening web' of security, as EU

\footnotetext{
$15 \mathrm{https}$ //thediplomat.com/2019/10/assessing-trumps-indo-pacific-strategy-2-years-in, accessed on 19 November 2019.

16 https://www.cnbc.com/2019/01/09/us-efforts-to-woo-back-asia-pacific-have-yet-to-take-effect.html, accessed on 19 November 2019.

${ }^{17} \mathrm{https}$ ///thediplomat.com/2019/10/assessing-trumps-indo-pacific-strategy-2-years-in, accessed on 19 November 2019.

18 https://www.cnbc.com/2019/01/09/us-efforts-to-woo-back-asia-pacific-have-yet-to-take-effect.html, accessed on 19 November 2019.

${ }^{19} \mathrm{https}: / /$ www.cnbc.com/2018/11/12/us-japan-and-indonesia-set-their-sights-on-the-indo-pacific-region.html, accessed on 19 November 2019.

${ }^{20} \mathrm{https}$ ://www.rand.org/pubs/research_reports/RR3125.html, accessed on 19 November 2019.

${ }^{21} \mathrm{https}$ //thediplomat.com/2019/10/assessing-trumps-indo-pacific-strategy-2-years-in, accessed on 29 March 2020.
} 
and ASEAN collectively offer their constituent participants an additional protection mechanism. ${ }^{22}$

\section{Conclusion}

If internal changes and external challenges force the EU and ASEAN to confront new issues to find the means to work together in novel ways, does this signify the reduced role of the region, or an opportunity for the EU and ASEAN to fill an institutional gap? In many ways, inter-regionalism is out of fashion, in the face of new global economic and security challenges and as novel institutional frameworks have come to the fore. However, one way of framing the ways in which regional bodies now function is through the idea of pragmatic inter-regionalism.

There is no doubt that the EU and ASEAN remain important to one another. On the one hand, the EU contributes approximately one third of all foreign direct investment (FDI) in ASEAN and remains the second largest trading partner. ${ }^{23}$ On the other, with a changing US posture, the rise of a complex web around Indo-Pacific, and the continued challenges posed by China, the EU and ASEAN have opportunities to balance regional relations and to provide some mutual protection, and to this end, inter-regional forums may be seen as part of the architecture and a pragmatic approach to region-to-region engagement on specific topics at particular moments (Rüland 2010: 1280). Whatever its shortcomings, the EU-ASEAN inter-regional dialogue is built on a solid foundation of mutual trust and able to cover a wide issue-led agenda to address concerns of interest to both regions. Two limiting factors in short- to medium-term cooperation will be the extent to which the EU's attention on the fall-out from Brexit preoccupies its negotiators, as well as the ways in which the consequences of the Covid-19 crisis are constructed as national, regional, inter-regional and/or international problems.

It may be, then, that a pragmatic approach to inter-regionalism offers a potential means to appreciate the necessary fluidity of institutional boundaries of interregionalism and the scope and remit of the issues it embraces, as well as the nature of the power balancing that takes place within and around it. Inter-regionalism, in these ways, can be seen to hold the potential to explain the role of regions in the current global context and should not be ignored as one important piece in a fluid and complex puzzle.

\section{References}

Acharya A (2015) “Alternative" regional institutions in Asia? A cautionary note. Georgetown J Asian Aff Spring/Summer 2:3-6

Acharya A (2004) How ideas spread: whose norms matter? Norm localization and institutional change in Asian regionalism. Int Organ 58(2):239-275

Aggarwal VK, Fogarty EA (eds) (2004) EU trade strategies: between regionalism and globalism. Palgrave Macmillan, Basingstoke

\footnotetext{
22 https://www.rand.org/pubs/research_reports/RR3125.html, accessed on 29 March 2020.

${ }^{23} \mathrm{https}$ //www.bilaterals.org/?is-there-an-eu-asean-trade-deal-on
} 
Aggarwal VK (1998) Reconciling multiple institutions: bargaining, linkages and nesting. In: Aggarwal VK (ed) Institutional designs for a complex world: bargaining, linkages, and nesting. Cornell University Press, Ithaca, pp 1-31

Auslin M (2012) Getting it right: Japan and Trans-Pacific Partnership. Asia-Pacific Rev 19(1):21-36

Beeson M, Xu S (2019) China's evolving role in global governance: the AIIB and the limits of an alternative international order. In: Zeng K (ed) Handbook on the international political economy of China. Edward Elgar, Cheltenham, pp 345-360

du Boisseau Rocher S (2012) The European Union, Burma/Myanmar and ASEAN: a challenge to European norms and values or a new opportunity? Asia-Europe J 10(2-3):165-180

Breslin S et al (eds) (2002) New regionalism in the global political economy: theories and cases. Routledge, London

Capling A (2008) Preferential trade agreements as instruments of foreign policy: an Australia-Japan free trade agreement and its implications for the Asia Pacific region. Pac Rev 21(1):27-43

Chin GT (2014) The BRICS-Led Development Bank: purpose and politics beyond the G20. Global Policy 5(3):366-373

Deng Y, Moore TG (2004) China views globalization: toward a new great-power politics? Wash Q 27(3):115136

Edgington T. (2020) Brexit: what trade deals has the UK done so far?' BBC news, 2 March. Available at https://www.bbc.co.uk/news/uk-47213842. Accessed on 27 March 2020

Elgot J., Sabbagh D. (2019) Japanese PM implores Britain not to leave EU without a deal. Guardian. 10 January. Available at https:/www.theguardian.com/politics/2019/jan/10/shinzo-abe-implores-britain-notto-leave-eu-without-a-deal. Accessed on 27 March 2020

Emmerson D (1995) Singapore and the "Asian Values" debate. J Democr 6(4):95-105

Fitriani E (2014) The impact of the EU crisis on EU-ASEAN relations. Geopolitics Hist Int Relat 6(1):78-93

Gilson J (2002) Asia Meets Europe. Edward Elgar, Cheltenham

Gilson J (2005) 'New Interregionalism? The EU and East Asia,'. J Eur Integr 27(3):307-26

Gilson J (2020) EU-Japan Relations and the Crisis of Multilateralism. Routledge, London

Goh E (2011) Institutions and the great power bargain in East Asia: ASEAN's limited "brokerage" role. Int Relat Asia-Pacific 11(3):373-401

J. Haacke $(2005,2003)$ ASEAN's diplomatic and security culture: origins, development and prospects (London: Routledge)

Helm T. (2018) Japan Ambassador's Brexit warning: there won't be a deal better than the single market. Guardian. 22 April. Available at https:/www.theguardian.com/politics/2018/apr/22/koji-tsuruoka-japanambassador-britain-brexit-single-market. Accessed on 27 March 2020

He K (2008) Institutional balancing and international relations theory: economic interdependence and balance of power strategies in Southeast Asia. Eur J Int Relat 14(3):489-518

Hettne B, Söderbaum F (2000) Theorising the rise of regionness. New Polit Econ 5(3):457-474

Hettne B et al (eds) (1999) Globalism and the new regionalism. Macmillan, London

Hurrell A (2007) One world? Many worlds? The place of regions in the study of international society. Int Aff 83(1):127-146

Hutt D (2019) 'EU struggles to strike trade pacts with major ASEAN countries,' Asia Nikkei, 4 August. Available at https://asia.nikkei.com/Politics/International-relations/EU-struggles-to-strike-trade-pactswith-major-ASEAN-countries. Accessed 19 Nov 2019

Kawai M., Wignaraja G. (2010) Asian FTAs: trends, prospects, and challenges. ADB economics working paper series 226. Available at https://www.think-asia.org/bitstream/handle/11540/1572/economicswp226.pdf? sequence=1. Accessed on 29 March 2020

Keohane RO et al (eds) (1993) After the cold war: international institutions and state strategies in Europe, 1989-1991. Harvard University Press, Cambridge

Khanna P (2014) New BRICS Bank a building block of alternative world order. New Perspect Q Fall 31:4648

Lam PE (2014) China's Asian infrastructure Investment Bank: East Asian responses. East Asian Policy 6(4): $127-135$

Maier-Knapp N (2016) The non-traditional security concept and the EUASEAN relationship against the backdrop of China's rise. Pac Rev 29(3):411-430

Mattheis F, Wunderlich U (2017) Regional actorness and interregional relations: ASEAN, the EU and Mercosur. J Eur Integr 39(6):723-738

Meissner KL (2016) A case of failed interregionalism? Analyzing the EU-ASEAN free trade agreement negotiations. Asia Eur J 14(3):319-336 
Nesadurai HES (2008) Southeast Asia's new institutional architecture for cooperation in economics and finance. In: Aggarwal VK, Koo MG (eds) Asia's new institutional architecture: evolving structures for managing trade, finance and security relations. Springer-Verlag, Berlin, pp 151-180

O'Carroll L. (2020) Brexit: UK negotiating objectives for trade with EU, in a Nutshell. Guardian. 27 February. Available at https:/www.theguardian.com/politics/2020/feb/27/brexit-uk-negotiating-objectives-fortrade-with-eu-in-a-nutshell. Accessed on 29 March 2020

Parameswaran P. (2020) Assessing Southeast Asia in the 2010s: 5 big strategic trends and how they may shape the 2020s. Diplomat. 1 January. Available at https://hediplomat.com/2020/01/assessing-southeastasia-in-the-2010s-5-big-strategic-trends-and-how-they-may-shape-the-2020s. Accessed on 29 March 2020

Peyrouse S. (2012) Europe's involvement in East Asian security: how to engage China. Eurasia Rev. 7 October. Available at https://www.eurasiareview.com/07102012-europes-involvement-in-east-asiansecurity-how-to-engage-china-analysis. Accessed on 29 March 2020

Politi J. et al. (2020) Trump and EU promise to press on to reach trade deal. Financ Times. 22 January. Available at https:/www.ft.com/content/988d8b3e-3d0f-11ea-b232-000f4477fbca. Accessed on 29 March 2020

Protopsaltis PM (2017) The development of the US and the EU preferential trade agreement networks: a tale of power and prestige. Neth Yearb Int Law 48:3-36

Rastogi V. (2018) CPTPP and opportunities for businesses in ASEAN. ASEAN Brief. 22 March. Available at https://www.aseanbriefing.com/news/2018/03/22/cptpp-opportunities-businesses-asean.html. Accessed on 29 March 2020

Rosamond B (2001) Constructing globalization. In: Fierke KM, Jørgensen KE (eds) Constructing international relations. M.E. Sharpe, Armonk, pp 201-219

Roy D (2005) Southeast Asia and China: balancing or bandwagoning? Contemp Southeast Asia 27(2):305322

Rüland J (2012) The rise of "diminished multilateralism": east Asian and European forum shopping in global governance. Asia Eur J 9:255-270

Rüland J (2011) Southeast Asian regionalism and global governance: "multilateral utility" or "hedging utility"? Contemp Southeast Asia 33(1):83-112

Rüland J (2010) Balancers, multilateral utilities or regional identity builders? International relations and the study of interregionalism. J Eur Public Policy 17(8):1271-1283

Rüland J (2007) Editorial: the politics of pragmatism: Southeast Asia's new free trade bilateralism. Südostasien aktuell: J Curr Southeast Asian Aff 26(1):7-13

Sbragia A (2010) The EU, the US, and trade policy: competitive interdependence in the management of globalization. J Eur Public Policy 17(3):368-382

Scholte JA (2000) Globalization: a critical introduction. Macmillan, Basingstoke

Scholte JA (1996) Globalisation and collective identities. In: Krause J, Renwick N (eds) Identities in international relations. Macmillan, London, pp 38-78

Shambaugh D (2013) Assessing the US "pivot” to Asia. Strateg Stud Q 7(2):10-19

Söderbaum F, Van Langenhove L (2005) Introduction: the EU as a global actor and the role of interregionalism. J Eur Integr 27(3):249-262

Stubbs R (2019) ASEAN sceptics versus ASEAN proponents: evaluating regional institutions. Pac Rev 32(6): 923-950

Stubbs R (2014) ASEAN's leadership in East Asian region-building: strength in weakness. Pac Rev 27(4): 523-541

Suzuki H (2017) The new politics of trade: EU-Japan. J Eur Integr 39(7):875-889

Tsuruoka M. (2016) Eikoku datsu de, jukutai ka no sakerarenai EU ga ikou - aratana ge-to e sagashi o semarareru nihon (The weakening of Japan-EU diplomacy is inevitable because of Brexit - Japan needs to seek another gateway to EU). Huffington Post Jpn. 12 July

Väyrynen R (2003) Regionalism: old and new. Int Stud Rev 5(1):25-51

Wagle A.A. (2018) How will ASEAN balance a tug of power between China and US-led "quad" in the indoPacific? Conversation. 24 October. Available at https://theconversation.com/how-will-asean-balance-atug-of-power-between-china-and-us-led-quad-in-the-indo-pacific-101468

Warleigh-Lack A et al (2011) New regionalism and the European Union: dialogues, comparisons and new research directions. Routledge, London

Wendt A, Duvall R (1989) Institutions and international order. In: Czempiel EO, Rosenau JN (eds) Global changes and theoretical challenges: approaches to world politics for the 1990s. Lexington Books, Lexington, pp 52-73 
Yeo LH (2018) The lessons from Brexit and its impact on Singapore and ASEAN. In: Huang DWF, Reilly M (eds) The implications of Brexit for East Asia. Springer, New York, pp 143-157

Publisher's note Springer Nature remains neutral with regard to jurisdictional claims in published maps and institutional affiliations. 